\title{
Institutional Influences on Manufacturing Organization in Multinational Corporations: The 'Cherrypicking' Approach
}

\author{
Accepted for publication in 'Organization Studies' in November 2004
}

\section{By Mike Geppert and Dirk Matten}

\author{
Mike Geppert \\ Centre for Business Management \\ Queen Mary, University of London \\ Mile End Road \\ London E1 4NS \\ United Kingdom \\ Tel. $+44(0) 2078827441$ \\ Fax. +44(0)20 78823615 \\ Email: m.geppert@qmul.ac.uk \\ Dirk Matten \\ School of Management \\ Royal Holloway, University of London \\ Egham, Surrey TW20 0EX \\ United Kingdom \\ Dirk.Matten@rhul.ac.uk \\ Phone +44 1784414018 \\ Fax +44 1784439854
}

Mike Geppert is a Reader in International Management Studies at the Centre for Business Management at Queen Mary, University of London. Mike holds a $\mathrm{PhD}$ in Organizational Sociology from Humboldt University in Berlin. His current research interests are in Institutional Theory, Comparative Organization Studies and International Management.

Dirk Matten is a Professor of Business Ethics in the School of Management at Royal Holloway, University of London. Dirk earned his $\mathrm{PhD}$ and the Habilitation in Business Studies from Heinrich-Heine-University Düsseldorf. His research interests include Comparative International Management, Business Ethics and Environmental Management. 


\title{
Institutional Influences on Manufacturing Organization in Multinational Corporations: The 'Cherrypicking' Approach
}

\begin{abstract}
Research in the multinational corporation (MNC) is increasingly concerned with the alleged evolution of companies towards a more standardized and rationalized global organisation. Only recently, this field has been informed by alternative approaches generating a more differentiated picture and considering the influence of divergent national institutional contexts on the multinational organisation. This paper makes a contribution to this debate from a comparative institutionalist perspective by focusing on manufacturing organization within MNCs. It argues that organization structures and processes in MNCs are sector specific and influenced by national institutional features of the home and host countries. Based on data from a specific industrial sector it identifies the crucial role of home country and host country embeddedness for the (re-)organization of manufacturing tasks and work systems. The key question is how actors shape the interaction of both institutional pressures and, with it, manufacturing approaches, location choices and work system designs. Research in British and German subsidiaries of three MNCs suggests that in particular at subsidiary level MNCs apply a 'cherrypicking' strategy of selected use of work system elements, shaped by the host country business system. It is shown that manufacturing strategies of MNCs originating from highly coordinated business systems are highly context specific and difficult (if not impossible) to transfer elsewhere. Moreover, 'cherrypicking' strategies in subsidiaries embedded in such contexts turned out to be highly problematic, especially when managers attempt to combine them with group-wide standardising work systems.
\end{abstract}

Descriptors: National business systems, work systems, enactment, Anglo-German comparison, multinational companies, manufacturing management 


\section{Introduction}

Research in the multinational corporation (MNC) during the last 30 years has been largely dominated by economic approaches (Morgan 2001). The thrust of the debate seems to be that evolutionary economic, technological and institutional isomorphisms will lead to more homogeneous organizational forms in MNCs (Bartlett and Ghoshal 1997), sometimes referred to as the 'Anglo-Saxonization' of international business activities (Ferner and Quintanilla 1998). The debate questions the persistence of national societal effects on the strategies and organizational design of MNCs in an increasingly internationalized business context (Meyer 2000; Mueller 1994; Ohmae 1990; Parker 1998: 50-51). Much of this interest in MNCs seems to have largely ignored the arguments raised by comparative institutional research over the last two decades. These studies have shown that production models such as Fordism or flexible specialization, are based on historically grown and highly idiosyncratic societal conditions which cannot easily be transferred from one society to another (Hollingsworth and Boyer 1997; Kristensen 1997). This research then - if linked with the recent debate on the MNC - could cast an interesting new light on the influence and persistence of national idiosyncrasies in MNCs.

This paper makes a contribution to the debate on MNCs from exactly this perspective. Drawing on the European institutionalist tradition, this paper shows that key institutional aspects of national business systems (NBS) which are assumed to differ among capitalist societies are still important in understanding local manufacturing approaches and work system designs, both MNC-wide and in localized settings (Whitley 1999). We will consider how divergent home country and host country institutional pressures interact in shaping work system designs of MNCs, especially the location and organization of group wide manufacturing tasks. A key question is, in other words, the influence of industry specificity as well as home and host country pressures on key actors in selecting certain manufacturing strategies and related work systems designs.

\section{The enactment of manufacturing and work systems in MNCs: The influence of industry specificity, home country and host country effects}

There is quite a considerable literature on the question as to why MNCs choose to locate their subsidiaries in certain countries. Most of this literature has been dominated by contingency and economic approaches (see Morgan et al. 2001). Although this literature acknowledges varying degrees of global standardization and convergence of organizational forms (Bartlett and Ghoshal 1989; Harzing 1999), the general view seems to be that a combination of global competition and mimetic isomorphism (copying of 'best practices'; by some termed as 'organizational effects', Mueller 1994), is resulting in the emergence of homogeneous strategies and network structures in 'global' MNCs across industrial sectors (Nohria and Ghoshal 1997).

This view is contested by institutionalist scholars who claim that national institutions and 'business systems' have a remaining and distinctive influence on dominant practices of firms in relation to work systems and, with it, the overall manufacturing approach of the firm (Lane 1992; Maurice 1980; Sorge 1991; 1996; Whitley 1999). Only recently, the question has been raised as to how and why international firms are likely to remain different (Whitley 2001). Therefore, it can be expected that both group-wide work systems of MNCs, as well work systems at the host country level, remain distinctive. Based on this debate, there are three key arguments we will draw on in this paper.

The first body of literature we draw on discusses historically grown, industrial sector specificities of innovativeness and competitiveness of certain production models. Most recently, authors such as Hollingsworth (2002) or Haake (2002) have offered a more 
comprehensive approach to understanding how industry-specific production models are intertwined with societal institutional arrangements. Fordist production models, it is argued, rely on a combination of short-term contractual market relations, corporate hierarchies as well as unegalitarian and short-lived networks (Hollingsworth and Boyer 1997). The development of standardized mass production is therefore seen as the typical approach of companies of Anglo-Saxon origin (see also Williams et al. 1983). In contrast to Fordist patterns, flexible specialization or diversified quality production (DQP), combining high quality and customization with volume, are seen as incompatible with neo-liberal deregulated regimes of capitalism. Therefore it is argued that 'the long term success of DQP requires a high degree of trust and cooperation among economic actors - between workers and managers within firms, and between firms on the hand, and their suppliers and customers on the other' (Hollingsworth and Boyer 1997: 24). This argument is developed further by Haake (2002), who distinguishes between individualistic business systems (e.g. the UK or the US), characterized by short-term employment, non-cooperative labor relations, market-based financial systems, arms-length relations between firms on the one hand and communitarian business systems (e.g. Germany and Japan) on the other hand, with long-term employment, union-management cooperation, close ties with banks, state support for industries, and close relations to suppliers and within industrial associations. The latter are seen as the reason why companies from Germany are more successful in industries requiring a high specificity of organizational knowledge, such as machine tools, but less suited in industries where organizational knowledge specificity is low, as for example, in financial services.

Comparative research on social production systems demonstrates impressively how differences in NBS characteristics are linked to a certain degree of organization-specificity of knowledge in an industrial sector. This significantly shapes industry specific competitive advantages of companies in a particular NBS. However, little is known about the implications of these industry specific advantages with regard to location decisions and work systems choices in MNCs. This study makes a contribution in this area.

There is, however, a second area of work which has started, at least in part, to fill this gap. Particularly relevant here is the work of Harzing (1999) which, by extending the mainstream contingency approach of the MNC, provides evidence that sector specific manufacturing strategies are also shaped by country of origin effects (CoE). More recently, Noorderhaven and Harzing (2003) have developed this idea further by arguing that CoE, such as differences in internationalization and control strategies of MNCs, can be ascribed to the different national origins of MNCs, rather than variations in their task environment.

The focus of this stream of research is mainly directed at the influence of CoEs on control approaches of MNCs (see also Harzing and Sorge 2003), and explains only one aspect of institutional influences, the effects of the home country. Moreover, the interplay of home and host country institutional pressures and the role of key actors in making choices about location and manufacturing organization are neglected.

Recently though, there seems to be a growing interest in interrelating CoEs and host country effects in MNCs, particularly with regard to host country subsidiaries where the NBS is significantly different from the one in the home country. This third literature has mainly focused on the areas of HRM (Edwards and Ferner 2002; Ferner 1997; Ferner et al. 2004; Ferner et al. 2000; Wächter et al. 2003) and employment and industrial relations (MullerCamen et al. 2001; Muller 1998; Turner et al. 1997) with recent expansion of the discussion to diffusion of work systems (Saka 2004). The latter work analyses how work system designs developed in the Japanese headquarters were actively translated and, with it, hybridized in the British subsidiaries. What is more and similar to our research in this paper, Saka focuses on 
how home country and host country institutional pressures interact by putting more emphasis on social action.

In line with the latter study, we argue that key actors do respond to institutional pressures by making choices about work system design and manufacturing organization and, with it, tightening or mitigating certain home and host country institutional pressures. Here we particularly refer to Weick (1979: 164) in assuming that the environment is 'selectively perceived, rearranged cognitively, and negotiated interpersonally'. Accordingly, the question we raise, is how the institutionalized environments of the home and the host country influence the selection and rearrangement of manufacturing organization and work system designs in MNCs.

Summarizing, we would then argue that our study is going beyond traditional comparative institutionalist studies in three respects: First, it focuses on how home and host country institutional legacies interact in shaping manufacturing organization and work systems. We assume, secondly, that home and host country institutional pressures are tightened and mitigated in enactment processes (Weick 1979) at various levels, headquarters (HQ) and subsidiaries, where key actors select certain elements of country specific work system designs. Thirdly, we will discuss the - in previous research rather neglected - case of institutional change within a societal context and its influence on MNC's manufacturing and work systems design by referring to the Finnish case of our study. This societal transformation process, as we will see, leads to certain decisions regarding the global manufacturing strategy and the selection of work system designs.

\section{Research Design and Methods}

This research is to investigate if, to what extent and in which ways actors within MNCs deliberately take into account certain elements of host country work systems in their groupwide manufacturing approach. We investigate this particular link in the sector of heavy engineering, in particular lifts \& escalators. Our primary aim is to find out how key actors in these organizations perceive certain elements of NBSs, and how work systems at group and subsidiary levels are enacted.

In this study we apply Whitley's work systems approach, which is closely intertwined with certain NBS features. Thus, 'work systems are characterized by contrasting ways of structuring tasks and jobs, of controlling how work is allocated, performed, and rewarded, and of structuring employment relationships' (Whitley 1999: 88). Key features are task organization and control, workplace relations between social groups, and employment practices and policies (for details see Tables 3 and 4, left columns). Furthermore and in correspondence with the discussion above, it is assumed that manufacturing strategies of MNCs, both at global and local level, are based on certain work system designs which are either predominantly Fordist or DQP methods, and which reflect (ideally) either the institutional features of more individualistic or more communitarian NBS (Haake 2002; Hollingsworth and Boyer 1997). Our main interest here then is how these institutional pressures were mitigated in the enactment processes, with actors deliberately selecting and combining some characteristics of work systems, while at the same time retaining or changing other elements of work system design in their manufacturing approaches.

We selected three out of the four major global players of a relatively small business sector, lifts \& escalators. The choice of this branch was based on the interests of this study: The lift \& escalator industry is characterized by a strong focus on the function of engineering as a substantial part of the value adding process during manufacturing. As earlier research has shown (Maurice et al. 1980), there is a particularly strong link between manufacturing and the 
national institutional framework, making the choice of manufacturing as a field of investigation for our purposes quite promising. Furthermore, the whole industrial sector is heavily affected by globalization pressures in terms of standardization of products, convergence of manufacturing technologies, as well as the emergence of a more transnational global market for the respective products (Iwer 2000).

Table 1 provides a basic overview of the companies, a U.S., a Finnish and a German MNC. All three companies were operating profitably and had recently (within the last five years) taken over former competitors, both globally and within the countries of our study.

\section{Table 1 should be placed here}

In order to allow for paired comparisons, we chose MNCs with national subsidiaries both in Germany and in the UK. The main reason for this selection is that both countries offer quite distinct cultural and institutional backgrounds which under many criterions offer antipodes of NBSs (Lane 1992). Furthermore, Anglo-German cross-cultural research has quite a long tradition in international business research so that we were able to build on quite a substantial body of literature (e.g. Lane 1992; 2000; 2001).

Our main source of data is qualitative. We developed interview guidelines and semistructured questionnaires in German and English for managers involved in or responsible for the design, change and implementation of work systems in their companies. A key aim was to select interviewees which were actively involved in strategic change processes, both at the national and international level. Table 2 provides an overview of the interviews conducted. In addition to this data, we used internal documents, in-house presentations, corporate publications, and coverage of the companies in the business press.

\section{Table 2 should be placed here}

We applied a multiple case study approach (Yin 1994) to compare both the focus of manufacturing strategies related to home country embeddedness and the host country-specific local adaptation. While it could be argued that this research method is limited in terms of generalizing across sectors (Hammersley and Gomm 2000), it nevertheless provides an indepth ethnographical study (Schofield 2000) of the relevance of national institutions on global manufacturing strategies of MNCs, and of the importance of locally enacted adaptations (Easterby-Smith et al. 2002: 50-51). In examining the contextual rationalities of MNCs ethnographic research has been proven as proficient (Sharpe 2004). A case study approach in international business issues is particularly recommended as institutionalist research in MNCs is still a rather recent phenomenon (Ghauri 2004).

In the following comparative discussion of our empirical findings, we will analyze the three MNCs in our sample within the context of our theoretical framework. This will first involve an analysis of global group-wide work systems and the way their enactment is influenced by the NBS of the MNC home country. The second step will be to analyze how these group wide manufacturing strategies, as defined above, are enacted in the different national subsidiaries in Germany and Britain respectively.

\section{The group wide manufacturing strategies of MNCs}


In this section we will briefly discuss the group wide manufacturing strategies of the three MNCs by comparing their group wide work systems. In doing so we want to make two points. First, we would like to show that all three companies have different strategies and work systems. Second, we argue that there is a link between the NBS of the country of origin of the MNC and their respective choice of work systems and manufacturing strategies. This analysis will then lay the basis for developing deviations from these group wide strategies, what we call 'cherrypicking', as the main theoretical contribution of this paper. While we have already analysed the group wide strategies and their link to the country of origin elsewhere (Geppert et al. 2003; Matten and Geppert 2004) we want to keep this section fairly brief and would chiefly refer to Table 3 which provides a detailed analysis of the comparative analysis of the group wide work systems.

\section{Table 3 should be placed here}

The U.S. MNC is a division of a larger conglomerate and reflects typical features of a Fordist work system which is typical of a MNCs with a U.S. home base (Faulkner et al. 2002; Ferner et al. 2004; Royle 2002; Wächter et al. 2003). The key goal of the U.S. company is to be the cost-leader (Porter 1980) in the global market for standardized lifts \& escalators. A focus on shareholder value led to the rationalization of global manufacturing plants by more than half, and a reduction of its worldwide R\&D facilities by more than two-thirds (Iwer 2000).

The German MNC is part of a conglomerate whose core division operates in the steel industry. Its group wise work systems are characteristic for DQP (Sorge and Streeck 1988) or 'flexible specialization' (Whitley 1999). The MNC shows an extensive number of characteristics typical of a large German conglomerate with a powerful engineering culture (Warner and Campbell 1993). It focuses on the high value market segment and has a strong focus on unit production and the development of customized solutions.

The Finnish MNC is the most interesting case in our sample because it reflects both the remaining influence as well as the institutional transition of the Finnish NBS (Laurila and Ropponen 2001; Lilja et al. 1992; Tainio 2001). Moving from bank and family-owned patterns to a shareholder-dominated ownership structure, the NBS is presently undergoing a significant shift towards being influenced by the international capital markets. Consequences include a 'financialization' (Tainio 2001) of organizations, more short-term horizons for business decisions, and a stronger focus on shareholders which often conflicts with employee interests. In terms of Bartlett and Ghoshal's (1989) model, the MNC is moving towards a 'global' company model, similar to the U.S. MNC. We would argue that the leadership of the Finnish MNC in technological innovations in lifts \& escalators is a reflection of the original Finnish NBS which is backed up by other studies on Finnish technology companies, such as Nokia and others (Lilja and Tainio 1996). As a reflection of the transition in the Finnish NBS the company applies a production system which attempts to combine technical excellence with product standardization. The company tries, on the one hand, to achieve cost-efficiency, and, on the other hand, develops products which allow quality leadership in mass markets for standardized commodities.

\section{The influence of host countries on work systems - German and British subsidiaries compared}

As we have seen, the group-wide work systems in the three MNCs of our sample differ quite considerably. However, when conducting our research at the subsidiary level, we were 
increasingly surprised by the relative homogeneity of work systems in the British and German operations of these MNCs. Table 4 provides an overview of the key characteristics of the work systems of the subsidiaries in both countries.

\section{Table 4 should be placed here}

\subsection{The German subsidiaries}

We start our discussion by looking at our German data, where the similarity of the three subsidiaries was most striking, as all three subsidiaries operate quite similar work systems, which are fairly closely aligned to the German NBS. Certainly the skill level is rather high compared to the British subsidiaries. For instance, in the German subsidiary with the highest skill level, 20\% of the employees have an engineering degree and $75 \%$ of the shop floor workers have a comprehensive vocational education ('Facharbeiterbrief'). By comparison, in the subsidiary with the highest skill level in Britain, only $4 \%$ had an engineering degree, and the workforce, if any, had only very selective formal qualifications in a limited range of skills ('National Vocational Qualifications').

Other characteristics of the work systems in the subsidiaries were equally similar: Generally, there was a high level of integration between different tasks, most notably R\&D, manufacturing and sales \& service. Chiefly due to the rather powerful role of trade unions and works councils in the German steel industry and also to some other institutional factors (such as the 'continuous improvement system'), all three subsidiaries had rather high levels of worker involvement and certain limits to managerial control of work organization. Similarly, the work systems in the area of workplace relations and employment practices were fairly similar across these subsidiaries.

While space does not permit us to elaborate on these characteristics in greater detail with evidence provided from our cases, our data does allow us to say that, on balance, the work systems in the German subsidiaries pretty closely match the characteristics of DQP. This work system type can be said to be fairly typical of the German NBS, as discussed earlier.

This finding is not particularly surprising in the case of the German MNC's subsidiary, where the group-wide work system, reflecting the CoE, is pretty much compatible with our findings here. They are, as one director put it, the only remaining site in the industry in Germany where an escalator can be produced 'from A to Z'. The work system of flexible specialization allows them to embark on their strategy of customized products for the more expensive segment of the global lift \& escalator market. In a certain sense then, the work system in their domestic subsidiary pretty much equates as the prototype for their global work systems.

The more interesting cases are the other two MNCs and their subsidiaries. Their group-wide work systems show characteristics somewhat incompatible with what their German subsidiaries would appear to have. If we first look at the U.S. MNC, it is interesting to see that while their group-wide work systems have quite a high level of fragmentation between various functions, the German subsidiary shows just the opposite. In this respect, the German subsidiary of the U.S. MNC is most similar to the German subsidiary of the German MNC. The reason for this is that the German subsidiary has a specific role within the U.S. MNC: It is one of the key locations for the development of high-tech components, such as electronic control equipment, as well as being the only production site for heavy-duty escalators within the global group, $85 \%$ of which are exported out of Germany to subsidiaries worldwide. In all our interviews it was agreed that the German subsidiary with their work systems was somewhat misplaced in this 'American culture'. At the same time, there was a clear 
perception that these specifics had a particular function for the entire MNC. With regard to the threat of losing manufacturing work due to high wages in Germany, the advantage of this German-style work system was explicitly underlined:

A manufacturing plant itself could be moved elsewhere quite easily, but the mixture of an engineering center and a manufacturing plant is far more complex. You could split the two on an organization chart, but in reality this link is hard to sever.

(Director HR, U.S. MNC Germany)

The cognitive perception of managers in the U.S. MNC seemed to be quite clearly the nature of work systems in Germany and their economic consequences which is enacted in their location decision in Germany:

...yeah, there is always this debate about 'high wage country Germany'. [...] up to now we have been convinced by high productivity and high standards of quality. [...]If I have a wage base of 1000 Marks an hour but am able to produce an escalator in three hours, then this is a marvelous result.

(Finance Director, U.S. MNC Germany)

Interestingly enough, the Finnish MNC, in whose portfolio the German subsidiary plays a similar role as a key $\mathrm{R} \& \mathrm{D}$ location, has recently attempted to change this strong interdependency of functions: While our interviewees stressed that the company wanted to benefit from strength in engineering and $R \& D$, the managers consistently chose Germany as its first location to manufacture a new standardized escalator series for the global group. Enacting the institutional environment, as it were, the R\&D Director of the German subsidiary underlined that - among other things such as the number of engineers and the skill level of workers - one of the reasons for choosing Germany was the low level of fragmentation in the work system as the engineering and $\mathrm{R} \& \mathrm{D}$ location was 'only a 5 minute walk from the manufacturing site'. However, the attempt to make use of these location factors while at the same time trying to cut the narrow link between R\&D and manufacturing on the one hand, and manufacturing and sales on the other, resulted in substantial conflicts and micro-political initiatives among key actors. Reflecting on the characteristics of the work systems, particularly the high level of worker's discretion and the strength of works councils, the fact that Germany is 'certainly not the hotbed of the corporate culture', as the director responsible for global IT at HQ put it, does not prevent the MNC from making use of some of the traits of the German work systems as a very crucial building block of its global operations. Standardizing products and manufacturing processes, and introducing new IT systems compatible with those in the global group and other group-wide work systems, as well as other standardization policies reduces worker's discretion and strengthens managerial control over the work organization. Particularly in the Finnish subsidiary, where these change processes were still underway, ongoing substantial tensions were reported in all interviews.

This tension between the German work system and the group-wide work systems in the U.S. MNC subsidiary is visible as well in the area of workplace relations between social groups. In particular, the role of works councils in both the American and the Finnish MNC was a rather contested one. As they are entitled to quite substantial influence on the design of work systems by law, their potential in interfering with global strategies implemented by local managers is substantial. No wonder then that we were met with palpable reservation among management concerning works councils, such as hearing claims that 'the works council is undoubtedly one of the most crucial disadvantages of Germany as a location for manufacturing' [HR Director U.S. MNC Germany] - or having them simply referred to with the use of expletives throughout the entire interview [Ger.: 'scheiss Betriebsrat', Director 
Controlling Systems, Finnish MNC Germany]. This contrasts quite substantially with the view in the German subsidiary of the German MNC:

Codetermination [...] is a social phenomenon which you simply accept if you accept a certain standard of civilization. [...] The relatively ritualized form of co-determination in Germany is clearly an advantage [...] this has now been practiced for so long that all parties involved know very well how to deal with each other.

(Head of Controlling, German MNC Germany)

In the area of employment practices and policies, the German subsidiaries all seem to operate quite similar policies, at least with regard to employees at lower levels of the organization. This is due to compliance with German employment legislation, although, again, there are considerable differences in attitude between the three MNCs. While the Finnish MNC was quite open about the fact that they would not hesitate to fire managers who continue to resist their new policies, one of the directors of the subsidiaries of the German MNC expressed in an interview that non-economical considerations occasionally dominate their employment decisions. So, for instance, a manager in the MNC's HQ mentioned that the priority in implementing ‘continuous improvement processes' was not primarily to save costs, but job security was seen as an equally important motivation.

Looking at the German subsidiaries of all three companies, we would argue that our research points to a key role of NBSs and their characteristic work systems in the decision of managers in MNCs to locate key manufacturing functions. This choice is relatively easy to understand in the case of the German MNC; the more interesting cases however are the U.S. MNC and its subsidiaries: why do companies whose group-wide aims of producing standardized products for a global mass market with a more or less Fordist approach to their group-wide work systems locate key operations in a country whose strengths in terms of work system characteristics are quite different from their group-wide strategy? Our answer from our data would be that these MNCs are only too well aware of the 'beneficial' characteristics of some of the 'constraints' (Streeck 1997) of the German NBS. Managers in the U.S. MNC had a particularly clear perception of the engineering and R\&D strengths of the German work system which they gave as the reason to source key components, as well as most of their global sales in more complex heavy-duty products out of their German operations. Equally, the key actors in the Finnish MNC, as a quickly growing organization, based their location decisions on German engineering and skills to launch the pilot manufacturing of a globally standardized product and aimed at 'extracting' selected local strengths of their German work systems to make them part of their global ones. Throughout our discussions with those key actors, in particular at group level, it seemed that these MNCs are trying to 'cherrypick' particular elements and characteristics of national specific work systems and attempting to integrate them into their global manufacturing strategies. In both companies, our interviews with key actors in the subsidiaries and at HQ level gave a clear indication that the German NBS and its characteristics were the reasons for their choice of manufacturing location. However, in our case studies the limits and problems of such a 'cherrypicking' strategy also surfaced. Work systems in the German subsidiary provided substantially powerful resources for resistance to the global strategy, particularly in the case of the Finnish MNC.

\subsection{The British subsidiaries}

The work systems of the British subsidiaries were not quite so similar on the surface as the German ones. However, there were some rather significant similarities and, overall, we would argue that - although in a different fashion - they echo and underscore our findings in the German subsidiaries: Despite some rather striking differences in the group-wide work 
systems of the MNCs of our sample, they all in some respect reflect the characteristics of the British NBS.

The most similar subsidiaries in terms of work systems and the recent changes applied to them are the American and the German MNC. This, in itself, is an noteworthy finding given that their group-wide work systems differ quite significantly. Both organizations have recently (that is between 1998-2001) closed their remaining manufacturing operations and restructured their work systems in a rather similar fashion, so that they are only providing sales and service to their customer, while sourcing the products from other plants within the multinational group. The U.S. MNC did it by laying off all existing employees in manufacturing and creating a centralized customer care centre in the Midlands with regional sales and service units throughout the UK. This represented a massive loss in skills given a strategy of newly employing only very narrowly skilled workers for the new tasks. The process unfolded somewhat differently in the German MNC, where only $9 \%$ of the workers were laid off and the rest were transferred into regional customer service centres. This slightly different approach, and the fact that they still retained a small workshop manufacturing site employing a small number (4\% of their workforce) of highly skilled staff, still seems to reflect the group-wide strategies at least in terms of targeting the upper market segment with more customized products.

Senior management in both companies stressed in the interviews that their respective groups applied this approach in the UK due to two reasons. First, the closure of manufacturing operations did not disrupt the sales and service functions of the organizations and second, employment laws allowed for quick and cost-efficient lay-offs. These changes then benefited particularly from a work system which is characterized by high levels of task fragmentation which allowed these organizations to quickly get rid of their manufacturing operations without incurring too much disruption to their other operations, most notably sales and services. We would argue, that in particular the latter shows that these actors were aware of the particular work system characteristics in the UK, most notably high levels fragmentation, and aligned the location and reorganization decisions accordingly.

A further facilitator of this rapid downsizing however is the UK employment law which allows for much quicker and less costly redundancies than, for instance, the German legal framework:

In the UK it is probably the easiest country in Europe to do different kinds of things. We really didn't have many obstacles...

(Director HR, US MNC UK)

This again supports our 'cherrypicking' argument that managers in MNCs deliberately take characteristics of the NBS as manifested in their subsidiaries into account in shaping their global operations. This is underscored by the case of the German MNC where the managing director explained that while the UK was considered to be 'bad at manufacturing', its newly established highly flexible and profitable service operations 'became a model for the whole of Europe' within the multinational group.

Both the American and the German MNC have adopted more or less a Fordist work system characteristic for much of post-1980s Britain (Lane 1992; Lane 1994). This applies also to the other characteristics of the work systems where there is low worker discretion and involvement in both organizations. Although there is a slightly stronger works council in the German MNC, workplace relations between social groups are fairly similar in both. Equally, employment practices and policies are similar in both subsidiaries and reflect the common practice in Britain: Interviewees in both companies stressed how easy it was to lay people off - 'much to the surprise of the HQ' as the managing director of the German subsidiary added. 
A somewhat different case is represented by the subsidiary of the Finnish MNC, which still has a sizable (350 employees) manufacturing plant for escalators in the North of England. They have a fairly highly skilled workforce, which produces small batches of highly customized heavy-duty escalators mostly for the domestic market where a number of customers still follow a 'buy British' philosophy. In addition, the plant serves as a buffer for their German subsidiary to cover for overcapacities in peak times. Though completely different from the two other MNCs, we would still argue that in the choice of location, this MNC also deliberately chose the British NBS because of its specific strength in the area of 'artisanal' manufacturing (Whitely 1999: 92) or 'specialized component production' (Sorge 1991: 169) of highly customized and technically sophisticated products. The strength of the British NBS here is that it is less determined as, for instance, the German and more open to sub-solutions and variations. As Sorge noted (1991: 167) 'the British organization is somewhat more equivocal' offering what he refers to as 'pockets of professionalism in maintenance, production, engineering, production control etc.' - of which the British subsidiary is a very good example. Though the subsidiary owes much of their work system infrastructure to the fact that it used to be a subsidiary of the German subsidiary of the Finnish MNC for more than 15 years, the work system very much exhibited the characteristics of this specific British work system variant: There was considerably low task fragmentation, a considerable amount of worker discretion and involvement, and rather close relations between managers and workers. In other words, the example of the subsidiary in Britain shows another incident of this 'cherrypicking' strategy: The company chose the UK as a location for a particular kind of manufacturing well-suited to the work system characteristics of the British NBS.

\subsection{The subsidiaries compared: logic and limits of a 'cherrypicking' strategy}

The six case studies on which this paper is based have revealed what we called a 'cherrypicking' approach by the MNCs in question. However limited, the cases seem to offer different rationales for such a strategy. In the case of the US MNC, our research revealed the logic of a rather deliberate decision in favour of a country due to certain institutional factors. It made specific use of the British NBS in changing their work systems to a sales and services only organization. The logic of 'cherrypicking' in the US MNC suggest more of a deliberate

choice between locations which also became evident throughout the German interviews using Germany in the sourcing of engineering and customized products for their entire multinational group. However, our reference to this imagery of 'cherrypicking' as the rationale for organizing and/or locating manufacturing aims at expressing the high degree of selectivity of this process, in that it is normally directed at a particular element of the respective national work system. In the case of the U.S. MNC in Germany, which has the longest legacy of this strategy, the subsidiary found itself in a rather peculiar position. While the managing director emphasized that the German subsidiary held considerable weight in the multinational group, the work systems themselves seemed relatively isolated within the group. Their main plant in rural Germany (Lower-Saxony) struck the researchers as a 'normal' German SME which, as it were, by mere coincidence has all its clients within the same MNC. In a similar vein, the second most important plant manufacturing high-tech components again had work systems in place not at all indicative of a plant belonging to a larger U.S.-multinational conglomerate. Staff, management and mentality were strongly German, even the language remained, with only top management being exposed to the culture, policies and language of the American HQ.

This relatively successful approach of 'cherrypicking' is also adopted by the Finnish MNC as well. However, the logic here seems to be somewhat more complex. The decision to buy the 
German subsidiary was never framed in terms of a choice for Germany as a location as such but more as growth by acquisition to become one of the four global market leaders. However, once the subsidiary was acquired, the decision to make Germany a central R\&D and manufacturing location was a result of a deliberate decision based on a benchmarking exercise between the German and U.S. subsidiaries. The decision based on perceived strength of the German institutional framework then seemed to have emerged over time and thus the logic of 'cherrypicking' is not only a deliberate decision (as in the US MNC) but also intertwined with path dependencies. This is even more evident in the British subsidiary: the subsidiary was part of a larger acquisition and the decision to continue manufacturing there evolved primarily from the strong market position of the subsidiary in a market which strictly speaking is not the main target segment of the multinational group. However, even though the 'cherrypicking' did not involve so strongly a deliberate choice, our case study data and interviews revealed quite clearly that the Finnish MNC sees its continuing engagement in the UK justified by certain institutional characteristics of the location. In particular, interviewees stressed the 'Buying British' approach of the London Underground and other large domestic customers as beneficial for the British subsidiary. 'New standard products...are going to Germany and I feel that more and more of the heavy duty big range will come to us', the Director of Manufacturing of the UK subsidiary explained, reflecting on the particular strengths of his subsidiary's work systems.

The HQ attempt to 'use' their German subsidiary as a launch pad for their globally standardized escalator manufacturing faced significant resistance at all levels of the plant. Their preliminary solution has been to replace the first and second level of national management with Finnish nationals and other executives from the HQ. This approach has been successful thus far. However, these experiences show that by 'cherrypicking' selective elements of the national work system (such as skill level or low task fragmentation) while trying to avoid others (such as specific workplace relations or employment practices) would appear to be highly problematic. Work systems obviously are not only deeply entrenched in the particular NBS and endure longer than corporate policies which try to use and 'instrumentalize' them, they are also deeply interdependent in their array and set of characteristics. In other words, 'the rules of the game [i.e. the institutional framework of the $N B S, D M / M G$ ] are usually longer-lived and more deeply entrenched than are the specific policies [i.e. globalization policies of MNCs, DM/MG][...] which they govern.' (Whitley 1997: 257). What we witnessed in our case studies then, is a strategy which can only be successful if the national work systems live a relatively isolated life within the MNC (American case) or if power is used to enforce separation between the desirable and the less preferred elements of the work systems (Finnish case).

Turning to the U.S. MNC in Britain, the 'cherrypicking' argument is not as strong (as Britain is actually quite hospitable to aspects of the group-wide work systems), but still visible: When local management decided to close down their manufacturing operations, the subsidiary initially lost a number of important contracts from public investors who still pursue a 'buy British' purchasing policy. The boundaries of this approach are also visible in the Finnish subsidiary in Britain: While investing on a moderate level in workforce skills and training (such as NVQs), the plant director complained in the interview that, due to the fact that service and maintenance in the industry is not very integrated in any one particular firm, quite a number in his workforce had been headhunted by competitors (the German and the American MNC that is) or other service providers. Moreover, local management complained that it was hard to find skilled labor, again a sign of the host country effects, featuring the shortcomings of the specialist and technical education in Britain. Table 5 provides an overview of the major options and limits of such a 'cherrypicking' approach by MNCs. 


\section{Table 5 should be placed here}

We did not associate this approach with the German MNC, as the company does not operate the same group-wide strategies with regard to its work systems. As a German MNC, they were fairly embedded in the German NBS, which did not require any selective approach in their domestic subsidiary. In the British subsidiary, the question of selecting part of the national work system did not play a role, as the HQ leaves wide autonomy to its subsidiary and - rather than 'cherrypicking' elements of a British work system pattern - allowed for an adaptation largely compatible with the national institutional framework.

\section{Discussion and conclusions}

This study addresses the so far sparsely discussed issue of how home and host country pressures interact in shaping group-wide work systems and manufacturing approaches. Coming back to Whitley's (2001) question of 'how and why are international firms different', we conclude, that the degree and sustainability of (local and (trans)national) institutional diversity of the MNC appears to be interdependently related to how and why key managers decide to standardize global manufacturing tasks and develop group-wide work system designs. The enactment of manufacturing organization is still largely influenced by the degree of institutional embeddedness of the MNCs as a whole, as well as its subsidiaries in distinct societal contexts. We have seen in the case of the German MNC that manufacturing strategies of MNCs originating from highly coordinated business systems are highly context specific and difficult (if not impossible) to transfer elsewhere. This cannot merely be interpreted as a symptom of evolutionary backwardness of this 'multi-domestic strategy', as Bartlett and Ghoshal presumably would put it but, rather, shows the remaining institutional distinctiveness of NBS and, with it, the COE. The company's manufacturing and work system design is strongly supported by the remaining idiosyncrasies of the German financial, educational and industrial relations systems.

While some argue that the German model of capitalism and the industrial relation system in particular is outmoded and an obstacle to attracting FDI (see Hans-Boeckler-Foundation 2004), this study suggests that institutional constraints are sector specific and remain beneficial to managers in those industries where German companies are traditionally highly competitive and innovative. The competitive advantages of the German subsidiaries in the lifts \& escalators sector emerged precisely because of the existence of national institutions based on a high degree of associated coordination mechanisms, and on collaborative relations between business and labour associations, just to name a few NBS elements. However, in other industrial sectors such as financial services or the computer industry, the same institutional arrangements might well be an impediment to more radical innovations (Hollingsworth 2002) - a possible reason why in these industries managers from communitarian NBS prefer to ‘cherrypick' companies and labour in Anglo-Saxon countries.

We would also argue that the CoE thesis helps to explain why the management of the U.S. MNC felt bound to move further towards low cost leadership based on standardized mass production, in a context in which the pressure to outsource certain manufacturing tasks to low wage countries is growing. Contrary to DQP, where close collaboration of manufacturing with service and R\&D functions is crucial, these tasks are much more fragmented in the Fordist production model and are therefore it appears to be easier for management to coordinate centrally (Hollingsworth 2002; Wächter et al. 2003).

However, in the Finish case we found a somewhat mitigated CoE. Reflecting the recent transformation of the Finnish business system, key actors began to redefine some of the 
established rules of the game, both internationally as well nationally, leading to the 'financialization' of many Finnish companies involved in international business. The small size of its home market, in contrast for example to Germany and the US, as well as its increasing openness to foreign investment, set the stage for significant changes in the corporate governance of leading home-based firms (Tainio et al. 2001). We would argue that in comparison to the rather large home economies of the other two MNCs, these global isomorphic tendencies and contingencies negatively moderate the strength of the $\mathrm{CoE}$ (Noorderhaven and Harzing 2003). Nevertheless, we have seen that certain elements of the traditional, more communitarian NBS are still relevant and continue to influence the company’s international manufacturing approach.

A key finding of this study was that the Anglo-Saxonization of group-wide work systems in two cases is going hand in hand with certain 'cherrypicking' strategies at the host country level. The British-German comparison shows that subsidiaries position themselves quite differently in the same industrial sector. On the one hand, we found strong similarities in the strategic approaches towards manufacturing in all three MNCs exploiting the 'beneficial constraints' (Streeck 1997) of the German NBS and its particular work system designs. On the other hand, we observed the low degree of institutional embeddedness of work systems in Britain which led to the closure of fragmented and poorly performing manufacturing units, as well as the narrow focus of subsidiaries on highly specialized production in one case.

Our analysis shows that attempts to transform DQP-based work systems into a more standardized global mass production approach is causing severe coordination problems and conflicts with local management and employees. This manufacturing approach is putting into question key features of the communitarian work system and will therefore most likely weaken its innovative capabilities and, with it, the institutional underpinnings of the 'cherrypicking' approach. Particularly interesting is the Finnish case where the decision to impose a global standardization of products and production process caused an increasing politicization of the German subsidiary as we have discussed in more detail elsewhere (Geppert 2003). This reaction indicates institutional differences of the underlying 'premises' or 'third order controls' between HQ and subsidiary managers about the focus of restructuring of the established manufacturing and work system design (Perrow 1986; Weick 1995). The production model imposed by the Finnish HQ is an attempt to replace this institutionally founded form of 'premise control' based on mutual trust across various hierarchical and functional levels with premises which favour standardized and formalized control. The key actors in the German subsidiary, however, remained committed to DQP which requires highly developed skills, knowledge and authority-sharing between management and employees at the firm level.

Our study evidences that managers enacting global manufacturing strategies tend to underestimate the interdependence of institutional settings and are rather selective when applying 'cherrypicking' approaches. We have seen that production models, such as DQP based on a highly organisation-specific work system design, cannot easily be transferred to other countries, which indeed explains the 'cherrypicking' strategy of the U.S. and the Finnish MNC. However, this strategy becomes problematic in certain industrial sectors of highly coordinated NBS when it is combined with global manufacturing approaches based on centralisation and standardization. 


\section{Acknowledgements}

We would like to thank the participants of the EGOS Standing Working Group 'Comparative Studies of Economic Organization' at the 2002 EGOS Colloquium for comments and suggestions. We are also indebted to Catherine Paradeise and two anonymous reviewers for invaluable feedback and critique which substantially improved our argument in this paper. We also thank Romano Dyerson for his generous support in polishing the language of the paper.

\section{References}

Bartlett, Christopher, and Sumantra Ghoshal

1989 Managing across borders: The transnational solution. 2 ed. Boston: Harvard Business School Press.

Bartlett, Christopher, and Sumantra Ghoshal

1997 'The transnational organization' in Organization theory: selected readings. D. S. Pugh (ed), 64-82. London: Penguin.

Easterby-Smith, Mark, Richard Thorpe, and Andy Lowe

2002 Management Research: An introduction. 2nd ed. London: Sage.

Edwards, Tony, and Anthony Ferner

2002 'The renewed 'American challenge': a review of employment practices in US multinationals'. Industrial Relations Journal 33/2: 94-111.

Faulkner, David, Robert Pitkethly, and John Child

2002 'International mergers and acquisitions in the UK 1985: a comparison of HRM practices'. International Journal of Human Resource Management 13/1: 106122.
Ferner, Anthony

1997 'Country of origin effects and HRM in multinational companies'. Human Resource Management Journal 7/1: 19-37.

Ferner, Anthony, and Javier Quintanilla 1998 'Multinationals, national business systems and HRM: The enduring influence of national identity or a process of 'Anglo-Saxonization". Journal of Human Resource Management 9/4: 710-731.

Ferner, Anthony, Mathias Z. Varul, and Jose Quintanilla

2000 'Country of Origin Effects, Host Country Effects and the Management of Human Resources in Multinationals: German Companies in Britain and Spain'. Journal of World Business 36: 107127.

Ferner, Anthony, Phil Almond, Ian Clark, Trevor Colling, Tony Edwards, Len Holden, and Michael MüllerCamen

2004 'The dynamics of central control and subsidiary autonomy in the management of human resources: Case study evidence from US MNCs in the UK'. Organization Studies 25/3: 363-391. 
Geppert, Mike

2003 'Sensemaking and politics in multinational companies: A comparative analysis of vocabularies within the global manufacturing discourse in one industrial sector'. Journal of Management Inquiry 12/4: 312329.

Geppert, Mike, Dirk Matten, and Karen Williams

2003 'Change Management in MNCs: How Global Convergence Intertwines with National Diversities'. Human Relations 56/7: 807-838.

\section{Ghauri, Pervez N}

2004 'Designing and conducting case studies in international businsess research' in Handbook of Qualitative Research Methods for International Business. R. Marschan-Piekkari and C. Welch (eds), forthcoming. Cheltenham: Edward Elgar.

Haake, Sven

2002 'National business systems and industry-specific competitiveness'. Organization Studies 23/5: 711736.

Hammersley, Martyn, and Roger Gomm 2000 'Introduction' in Case Study Method. R. Gomm, M. Hammersley, and P. Foster (eds), 1-16. London: Sage.

Hans-Boeckler-Foundation

2004 'Zur aktuellen Kritik der Mitbestimmung im Aufsichtsrat', Fakten fuer eine faire Arbeitswelt. Duesseldorf.

Harzing, Anne-Will

1999 Managing the multinationals: An international study of control mechanisms Cheltenham, UK: Edward Elgar.
Harzing, Anne-Will, and Arndt Sorge

2003 'The relative impact of country of origin and universal contingencies on internationalization strategies and corporate control in multinational enterprises: worldwide and European perspectives'. Organization Studies 24/2: 187-214.

Hollingsworth, J. Rogers, and Robert Boyer

1997 'Coordination of economic actors and social systems of production' in Comtemporary capitalism: the embeddedness of institutions. J. R. Hollingsworth and R. Boyer (eds), 1-47. Cambrigde: Cambridge University Press.

Hollingsworth, J. Rogers

2002 'Some reflections on how institutions influence styles of innovation', Paper presented to the Swedish Collegium for Advanced Study in the Social Sciences. Stockholm.

Iwer, Frank

2000 Innovationstrends in der Aufzugsindustrie und Folgen für die Beschäftigungssituation. Projektabschlußbericht Stuttgart: IG-Metall.

Kristensen, Peer Hull

1997 'National systems of governance and managerial prerogatives in the evolution of work systems:

England, Germany and Denmark compared' in Governance at work: The social regulation of economic relations. $\mathrm{R}$. Whitley and $\mathrm{P}$. $\mathrm{H}$. Kristensen (eds), 3-46. Oxford: Oxford University Press.

Lane, C

1994 'Industrial order and the transformation of industrial relations: Britain, Germany and 
France' in New frontiers in

European industrial relations. R. Hyman and A. Ferner (eds), 167195. Oxford: Blackwell.

Lane, Christel

1992 'European business systems: Britain and Germany compared' in European business systems. R. Whitley (ed), 64-97. London: Sage.

Lane, Christel

2000 'Understanding the globalization strategies of German and British multinational companies' in Embedding organizations: societal analysis of actors, organizations, and socio-economic context. $\mathrm{M}$. Maurice and A. Sorge (eds), 188208. Amsterdam/Philadelphia: John Benjamins.

Lane, Christel

2001 'The emergence of German transnational companies: a theoretical analysis and empirical study of the globalization process' in The multinational firm. G. Morgan, P. H. Kristensen, and R. Whitley (eds), 69-96. Oxford: Oxford University Press.

Laurila, Juha, and Minna Ropponen

2001 'Sustaining homogeneity in the forms of foreign expansion: some evidence from the Finnish-based forest industries'. Paper presented at the ESRC Transnational Communities Programme Conference Warwick 2001.

Lilja, Kari, Keijo Räsänen, and Risto Tainio

1992 'A dominant business recipe: the forest sector in Finland' in European business systems. R. Whitley (ed), 137-154. London: Sage.

Matten, Dirk, and Mike Geppert
2004 'Work systems in heavy engineering: the role of national culture and national institutions in multinational corporations'. Journal of International Management 10/2: 177-198.

Maurice, Marc

1980 'Societal differences in organizing manufacturing units: A comparison of France, West Germany and Great Britain'. Organization Studies 1/1: 59-86.

Maurice, Marc, Arndt Sorge, and Malcolm Warner

1980 'Societal differences in organizing manufacturing units: A comparison of France, West Germany and Great Britain'. Organization Studies 1/1: 59-86.

Meyer, J.W.

2000 'Globalization - Sources and Effects on National States and Societies'. International Sociology 15: 233-248.

Morgan, Glenn

2001 'The multinational firm: organizing across institutional and national divides' in The multinational firm. G. Morgan, P. H. Kristensen, and R. Whitley (eds), 1-24. Oxford: Oxford University Press.

Morgan, Glenn, Peer Hull Kristensen, and Richard Whitley

2001 The multinational firm. Oxford: Oxford University Press.

Mueller, Frank

1994 'Societal effect, organisational effect, and globalization'. Organization Studies 15/3: $407-$ 428.

Muller-Camen, M., Phil Almond, Patrick Gunnigle, Jose Quintanilla, and Anne Tempel 
2001 'Between home and host country: multinationals and employment relations in Europe'. European Industrial Relations 32/5: 435-448.

Muller, M.

1998 'Human Resource and Industrial Relations Practices of UK and US Multinationals in Germany'. International Journal of Human Resource Management 9/4: 732749.

Nohria, Nitin, and Sumantra Ghoshal 1997 The differentiated network. Organizing multinational corporations for value creation San Francisco: Jossey-Bass.

Noorderhaven, N.G., and Anne-Will Harzing

2003 'The "Country-of-origin-effect" in multinational coporations: Sources, mechanisms and moderating conditions'. Management International Review 42/2: 47-66.

Ohmae, $\mathrm{K}$

1990 The borderless world: power and strategy in the interlinked economy New York: Free Press.

Parker, Barbara

1998 Globalization and business practice: managing across boundaries London: Sage.

Perrow, Charles

1986 Complex organizations. 3rd ed. New York: Random House.

Porter, Michael

1980 Competitive strategy: Techniques for Analysing industries and competitors New York: Free Press.

Royle, Tony

2002 'Resistance is useless! The problem of Trade Union organization in the European Fast-food industry: The case of McDonald's' in Challenges for European management in a global context: Experiences from Britian and Germany. M. Geppert, D. Matten, and K. Williams (eds), 189-214. Basingstoke: Palgrave.

Saka, Ayse

2004 'The cross-national diffusion of work systems: translation of Japanese operations in the UK'. Organization Studies 25/2: 209228.

Schofield, Janet W.

2000 'Increasing the generalizability of qualitative research' in Case Study Method. R. Gomm, M.

Hammersley, and P. Foster (eds), 69-97. London: Sage.

Sharpe, Diana

2004 'The Relevance of Ethnographic Studies to International Business Research' in Handbook of Qualitative Research Methods for International Business. R. Marschan-Piekkari and C. Welch (eds), forthcoming. Cheltenham: Edward Elgar.

Sorge, Arndt, and Wolfgang Streeck 1988 'Industrial relations and technical change: The case for an extended perspective' in New technology and industrial relations. R. Hyman and W. Streeck (eds), 19-47. Oxford: Blackwell.

Sorge, Arndt

1991 'Strategic fit and societal effect interpreting cross-national comparisons of technology, organization and human resources'. Organization Studies 12/2: 161190.

Sorge, Arndt

1996 'Societal effects in cross-national organization studies: conceptualizing diversity in actors and systems' in The changing 
European firm. R. Whitley and P. H. Kristensen (eds), 67-86.

London: Routledge.

Streeck, Wolfgang

1997 'Beneficial constraints:on the economic limits of rational voluntarism' in Contemporary capitalism: the embeddedness of institutions. J. R. Hollingsworth and R. Boyer (eds), 197-219. Cambridge: Cambridge University Press.

Tainio, Risto: 2001. Effects of foreign portfolio investors on Finnish companies and their management. Paper presented at the Paper presented at the 17th EGOS Colloquium Lyon July 2001.

Tainio, Risto, M Huolman, and $\mathrm{M}$ Pulkkinen

2001 'The internationalization of capital markets: how international institutional investors are restructuring Finnish companies' in The multinational firm. G. Morgan, P. H. Kristensen, and R. Whitley (eds), 153-171. Oxford: Oxford University Press.

Turner, Thomas, Daryl D'Art, and Patrick Gunnigle

1997 'Pluralism in retreat? A comparison of Irish and multinational manufacturing companies'. International Journal of Human Resource Management 8/6: 823840.

Wächter, Hartmut, René Peters, Anne Tempel, and Michael MüllerCamen

2003 The 'country of origin effect' in the cross-national management of human resources Munich: Rainer Hampp.

Warner, Malcolm, and Adrian Campbell
1993 'German Management' in Management in Western Europe. Society, culture and organization in twelve nations. D. J. Hickson (ed), 89-108. Berlin/ New York: De Gruyter.

Weick, Karl E.

1979 The social psychology of organizing. 2 ed. New York: McGraw-Hill.

Weick, Karl E.

1995 Sensemaking in organizations Thousand Oaks: Sage.

Whitley, Richard

1997 'The social regulation of work systems: Institutions, interest groups, and varieties of work organization in capitalist societies' in National Capitalisms, Global Competition, and Economic Performance. S. Quack, G. Morgan, and R. Whitley (eds), 227260. Amsterdam, Philadelphia: John Benjamins Publishing Company.

Whitley, Richard

1999 Divergent capitalisms. The social structuring and change of business systems Oxford: Oxford University Press.

Whitley, Richard

2001 'How and why are international firms different? The consequences of cross-border managerial coordination for firm characteristics and behaviour' in The multinational firm: Organizing across institional and national divides. G. Morgan, P. H. Kristensen, and R. Whitley (eds), 27-68. Oxford: Oxford University Press.

Williams, Karel, John Williams, and Dennis Thomas 
1983 Why are the British bad at manufacturing? London: Routledge \& Kegan Paul.
1994 Case Study Research: Design and Methods. 2nd ed. Thousand Oaks, CA: Sage.

Yin, Robert K. 


\begin{tabular}{|c|c|c|c|}
\hline & U.S. MNC & Finnish MNC & German MNC \\
\hline Total number of employees worldwide & 63,000 & 23,000 & 28,500 \\
\hline Proportion of employees abroad & $84 \%$ & $94 \%$ & $93 \%$ \\
\hline Proportion of sales abroad & $76 \%$ & $91 \%$ & $89 \%$ \\
\hline No. of countries with overseas subsidiaries & 200 & 40 & 102 \\
\hline No. of overseas manufacturing plants & 40 & 14 & 23 \\
\hline $\begin{array}{l}\text { Size of German subsidiary: } \\
\text { sales (in Million Euro) } \\
\text { employees }\end{array}$ & $\begin{array}{l}700 \\
4000 \\
\end{array}$ & $\begin{array}{l}243 \\
1800\end{array}$ & $\begin{array}{l}421 \\
1822 \\
\end{array}$ \\
\hline $\begin{array}{l}\text { Size of UK subsidiary } \\
\text { Sales (in Million Euro) } \\
\text { Employees } \\
\end{array}$ & $\begin{array}{l}144 \\
2700\end{array}$ & $\begin{array}{l}205 \\
1295\end{array}$ & $\begin{array}{l}120 \\
800\end{array}$ \\
\hline
\end{tabular}

Sources: Annual Reports 2001 and interviews by the authors

Table 1: Basic data of the companies studied

\begin{tabular}{|c|c|c|c|}
\hline & U.S. MNC & Finnish MNC & German MNC \\
\hline At HQ & $\begin{array}{l}\text { Member of the } \\
\text { Executive Board }\end{array}$ & $\begin{array}{l}\text { - Head of Management } \\
\text { Development } \\
\text { - Director of Roll Out } \\
\text { and Administration } \\
\text { Support }\end{array}$ & $\begin{array}{l}\text { - Member of the } \\
\text { Executive Board } \\
\text { - Head of Accounting } \\
\text { and Internal Auditing }\end{array}$ \\
\hline $\begin{array}{l}\text { In German } \\
\text { subsidiary }\end{array}$ & $\begin{array}{l}\text { - Finance Director } \\
\text { - Director Quality } \\
\text { - Director Human } \\
\text { Resources } \\
\text { - Director Service and } \\
\text { Maintenance }\end{array}$ & $\begin{array}{l}\text { - Managing Director } \\
\text { - Director R\&D } \\
\text { - Director Controlling } \\
\text { Systems }\end{array}$ & $\begin{array}{l}\text { - Head of Controlling } \\
\text { - Head of R\&D } \\
\text { - Commercial Director } \\
\text { - Head of the Works } \\
\text { Council and Member } \\
\text { of European Works } \\
\text { Council } \\
\end{array}$ \\
\hline In UK subsidiary & $\begin{array}{l}\text { - } \text { Director Human } \\
\text { Resources } \\
\text { - } \text { Regional Service } \\
\text { Manager } \\
\text { - Regional Service } \\
\text { Manager }\end{array}$ & $\begin{array}{l}\text { - Managing Director } \\
\text { - Director Engineering } \\
\text { - Director of } \\
\text { Manufacturing Plant }\end{array}$ & $\begin{array}{l}\text { - Managing Director } \\
\text { - Director of a } \\
\text { Regional service } \\
\text { Centre } \\
\text { - Head of group-wide } \\
\text { UK Works Council } \\
\text { and Member of } \\
\text { European Works } \\
\text { Council } \\
\text { - Regional Service } \\
\text { Manager and } \\
\text { Member of Works } \\
\text { Council of one } \\
\text { Service Centre } \\
\end{array}$ \\
\hline
\end{tabular}

(conducted between May 2000 and June 2001)

Table 2: The conducted interviews 


\begin{tabular}{|c|c|c|c|c|}
\hline \multicolumn{2}{|c|}{$\begin{array}{l}\text { Characteristics of } \\
\text { Work systems }\end{array}$} & U.S. MNC & Finnish MNC & German MNC \\
\hline \multicolumn{2}{|c|}{$\begin{array}{l}\text { General type of } \\
\text { group-wide work system }\end{array}$} & $\begin{array}{l}\text { Fordist } \\
\text { - Orientation towards mass markets } \\
\text { - Standardized products and large scale } \\
\text { production } \\
\text { - Low level of skills in manufacturing plants } \\
\text { - Cost leadership }\end{array}$ & $\begin{array}{l}\text { Delegated responsibility towards Fordist } \\
\text { - Orientation towards mass markets } \\
\text { - Standardized products and large scale } \\
\text { production } \\
\text { - Medium level of skills in manufacturing plants } \\
\text { - Technology leadership }\end{array}$ & $\begin{array}{l}\text { Flexible Specialization } \\
\text { - Orientation towards top end niche of the } \\
\text { market } \\
\text { - Customized products and order production } \\
\text { - High level of skills in manufacturing plants } \\
\text { - Quality leadership }\end{array}$ \\
\hline \multirow{4}{*}{$\begin{array}{l}\text { Task } \\
\text { organization } \\
\text { and control }\end{array}$} & Skill level & $\begin{array}{l}\text { Low } \\
\text { - Skills are kept at the lowest possible level, } \\
\text { focus on low skill demanding repetitive work } \\
\text { patterns in manufacturing and service }\end{array}$ & $\begin{array}{l}\text { Medium to low } \\
\text { - Skill level is low in manufacturing plants, but } \\
\text { relatively higher in those locations which } \\
\text { have a R\&D function for the entire group }\end{array}$ & $\begin{array}{l}\text { High } \\
\text { - Skill level and its maintenance is a high } \\
\text { priority in all subsidiaries and at group level }\end{array}$ \\
\hline & Fragmentation & $\begin{array}{l}\text { High } \\
\text { - R\&D, manufacturing, Sales and Service are } \\
\text { all organizationally and geographically } \\
\text { separate }\end{array}$ & $\begin{array}{l}\text { High } \\
\text { - Recent reorganization into 'front line' and } \\
\text { 'supply line' separates manufacturing and } \\
\text { R\&D from sales and service functions }\end{array}$ & $\begin{array}{l}\text { Low } \\
\text { - Decentralized organisation of R\&D, } \\
\text { manufacturing, sales and services across the } \\
\text { multinational group allows for dense } \\
\text { intearation of functions }\end{array}$ \\
\hline & $\begin{array}{l}\text { Worker discretion } \\
\text { and involvement }\end{array}$ & $\begin{array}{l}\text { Low } \\
\text { - Standardization of products leaves little } \\
\text { scope for worker's involvement }\end{array}$ & $\begin{array}{l}\text { Medium to low } \\
\text { - The focus on high technology solutions } \\
\text { allows for worker's involvement in R\&D } \\
\text { locations; } \\
\text { - The long term aim for the group though is to } \\
\text { standardize products and manufacturing } \\
\text { processes globally which minimizes workers' } \\
\text { discretion }\end{array}$ & $\begin{array}{l}\text { High } \\
\text { - Management at group level put high } \\
\text { emphasis on the development and use of } \\
\text { local knowledge } \\
\text { - extensive involvement of workers in } \\
\text { innovation, quality management and other } \\
\text { work systems design measures }\end{array}$ \\
\hline & $\begin{array}{l}\text { Managerial control } \\
\text { of work } \\
\text { organization }\end{array}$ & $\begin{array}{l}\text { High } \\
\text { - Strong 'performance culture' based on } \\
\text { financial control measures } \\
\text { - Growing centralization of managerial control } \\
\text { in the US (recent closure of European sub- } \\
\text { HQ) } \\
\text { - Centrally devised product policy and } \\
\text { marketing strategies }\end{array}$ & $\begin{array}{l}\text { High to Very High } \\
\text { - Globally standardised management system } \\
\text { for all business processes imposed by HQ to } \\
\text { subsidiaries } \\
\text { - Rapid growth through acquisition over the } \\
\text { last decade leads to authoritarian and power- } \\
\text { based imposition of the new standardised } \\
\text { management system }\end{array}$ & $\begin{array}{l}\text { Medium } \\
\text { - Relatively high in the choice of market } \\
\text { segment (high value products) and focus on } \\
\text { complex engineering solution which is a } \\
\text { global strategy of the MNC } \\
\text { Relatively low in assigning each subsidiary a } \\
\text { maximum degree in the choice of } \\
\text { technologies, work systems design and local } \\
\text { market strategy leading to heterogeneous } \\
\text { subsidiaries }\end{array}$ \\
\hline
\end{tabular}

Table 3: The group wide work systems of the MNCs compared (to be continued on next page) 


\begin{tabular}{|c|c|c|c|c|}
\hline \multirow{2}{*}{$\begin{array}{l}\text { Workplace } \\
\text { relations } \\
\text { between social } \\
\text { groups }\end{array}$} & $\begin{array}{l}\text { Separation of } \\
\text { managers from } \\
\text { workers }\end{array}$ & $\begin{array}{l}\text { High } \\
\text { - Centralisation of decision making in the US; } \\
\text { strong emphasis on financial co-ordination } \\
\text { and control mechanisms implement palpable } \\
\text { divide between 'the controllers' and 'the } \\
\text { controlled' } \\
\text { - Group-wide hierarchy selectively favours } \\
\text { financial management skills and downgrades } \\
\text { engineering and technical skills }\end{array}$ & $\begin{array}{l}\text { High } \\
\text { - The management system centralises } \\
\text { decision making and implements a tight } \\
\text { financial controlling system to the entire } \\
\text { group } \\
\text { - At subsidiary level influences of British } \\
\text { artisanal or German DQP system seem to } \\
\text { prevail with the result of mitigated effects of } \\
\text { the group wide work system }\end{array}$ & $\begin{array}{l}\text { Medium to Low } \\
\text { - Both subsidiaries revealed high levels of } \\
\text { participation in the design and reorganisation } \\
\text { of work systems } \\
\text { - Employee representatives on the board of } \\
\text { the group involves workers' representatives } \\
\text { from all subsidiaries in many decisions of } \\
\text { strategic importance for local subsidiaries }\end{array}$ \\
\hline & $\begin{array}{l}\text { Strength of trade } \\
\text { unions/Works } \\
\text { councils }\end{array}$ & $\begin{array}{l}\text { Low } \\
\text { Subsidiaries had either no significant union } \\
\text { representation or - where required by law - } \\
\text { were considered as a necessary evil and } \\
\text { 'location disadvantage' ('Standortnachteil') } \\
\text { - Multiple cases of union 'avoidance' or } \\
\text { 'circumvention' strategies were observed }\end{array}$ & $\begin{array}{l}\text { Low to Medium } \\
\text { - Attitude of management on group level see } \\
\text { unions as an impediment to a swift } \\
\text { implementation of their global management } \\
\text { systems } \\
\text { - At local level - depending on local } \\
\text { employment law - works councils had } \\
\text { constructive working relations with } \\
\text { management }\end{array}$ & $\begin{array}{l}\text { High } \\
\text { - All subsidiaries had strong union } \\
\text { representations and works councils; UK head } \\
\text { of works councils' self assessment was his } \\
\text { position was strongest in UK compared to } \\
\text { other MNCs } \\
\text { - Senior management considers strong legal } \\
\text { position of works councils as a strength in } \\
\text { favour of stable and predictable relations to } \\
\text { work force }\end{array}$ \\
\hline
\end{tabular}

\section{Table 3: The group wide work systems of the MNCs compared (to be continued on next page)}




\begin{tabular}{|c|c|c|c|c|}
\hline \multirow{2}{*}{$\begin{array}{l}\text { Employment } \\
\text { practices and } \\
\text { policies }\end{array}$} & $\begin{array}{l}\text { Employer } \\
\text { commitment to } \\
\text { employment } \\
\text { security for core } \\
\text { workforce }\end{array}$ & $\begin{array}{l}\text { Low } \\
\text { - All subsidiaries experience constant threat of } \\
\text { closure in favour of locations in 'low cost } \\
\text { countries' } \\
\text { - Restructuring from manufacturing to sales } \\
\text { and service only in Britain led to redundancy } \\
\text { of all former staff and subsequent re- } \\
\text { employment of new (lower skilled) staff }\end{array}$ & $\begin{array}{l}\text { Medium } \\
\text { - Management rhetoric suggests clear } \\
\text { preference for maximising shareholder value; } \\
\text { management practice though reveals some } \\
\text { concern for employment security }\end{array}$ & $\begin{array}{l}\text { High } \\
\text { - Board members see shareholder return just } \\
\text { as one goal while keeping employment } \\
\text { secure ranges as equally important } \\
\text { - Unavoidable layoffs are carried out with } \\
\text { careful consideration of social situation of } \\
\text { employees }\end{array}$ \\
\hline & $\begin{array}{l}\text { Employer } \\
\text { commitment to } \\
\text { skill development }\end{array}$ & $\begin{array}{l}\text { Low } \\
\text { - No group wide policies and initiatives to skill } \\
\text { development were observed }\end{array}$ & $\begin{array}{l}\text { Low } \\
\text { - At group level, high skilled engineering staff } \\
\text { is employed to ensure technology based cost } \\
\text { leadership in mass markets } \\
\text { - At shop floor level in the subsidiaries, little } \\
\text { emphasis is laid on skill development } \\
\end{array}$ & $\begin{array}{l}\text { Medium to High } \\
\text { - Numerous initiatives by group wide works } \\
\text { councils/European works councils towards } \\
\text { skill development } \\
\text { - Due to relative autonomy of subsidiaries } \\
\text { considerable differences in initiatives on local } \\
\text { level (German subsidiary had a large number } \\
\text { of programmes, British subsidiary did not } \\
\text { show much sign of systematic skill } \\
\text { development) }\end{array}$ \\
\hline
\end{tabular}

Table 3: The group wide work systems of the MNCs compared 


\begin{tabular}{|c|c|c|c|}
\hline & & $\begin{array}{c}\text { The subsidiaries in } \\
\text { Germany }\end{array}$ & $\begin{array}{c}\text { The subsidiaries in } \\
\text { Britain }\end{array}$ \\
\hline \multirow{4}{*}{$\begin{array}{l}\text { Task } \\
\text { organization } \\
\text { and control }\end{array}$} & Skill level & $\begin{array}{l}\text { High in all subsidiaries } \\
\text { All subsidiaries had high levels of skills among shop floor workers, } \\
\text { senior staff on the shop floor and engineering staff in construction } \\
\text { and R\&D }\end{array}$ & $\begin{array}{l}\text { U.S. MNC: Low } \\
\text { Recent changes aimed at lowering skill level } \\
\text { Finish MNC: Medium } \\
\text { German MNC: Low } \\
\text { small aroup of hiahly skilled workers for customization at } \mathrm{HO}\end{array}$ \\
\hline & Fragmentation & $\begin{array}{l}\text { U.S. MNC, German MNC: Low } \\
\text { High level of integration of manufacturing, R\&D, and sales functions } \\
\text { Finish MNC: low to medium } \\
\text { Recent efforts to separate manufacturing and R\&D functions met acute } \\
\text { resistance }\end{array}$ & $\begin{array}{l}\text { U.S. MNC, German MNC: High } \\
\text { Strong separation between manufacturing and service } \\
\text { Finish MNC: Low } \\
\text { Sales \& service well integrated with small batch craft production }\end{array}$ \\
\hline & $\begin{array}{l}\text { Worker discretion } \\
\text { and involvement }\end{array}$ & $\begin{array}{l}\text { U.S. MNC: High } \\
\text { Finish MNC: High } \\
\text { Though recent tensions arose because of reduced discretion } \\
\text { German MNC: Very High } \\
\text { Various initiatives and policies to increase involvement }\end{array}$ & $\begin{array}{l}\text { U.S. MNC: Very Low } \\
\text { Finish MNC: Medium } \\
\text { German MNC: Very Low }\end{array}$ \\
\hline & $\begin{array}{l}\text { Managerial control } \\
\text { of work } \\
\text { organization }\end{array}$ & $\begin{array}{l}\text { U.S. MNC: Medium to High } \\
\text { IThough shared with works council ('Mitbestimmung') } \\
\text { Finish MNC: Medium to High } \\
\text { Clashes with works councils and their legal entitlements } \\
\text { German MNC: Medium } \\
\text { Though shared with works council ('Mitbestimmung') }\end{array}$ & $\begin{array}{l}\text { U.S. MNC, German MNC: Very High } \\
\text { Finish MNC: Medium } \\
\text { A distinct amount of shared control with workers takes place }\end{array}$ \\
\hline \multirow{2}{*}{$\begin{array}{l}\text { Workplace } \\
\text { relations } \\
\text { between social } \\
\text { groups }\end{array}$} & $\begin{array}{l}\text { Separation of } \\
\text { managers from } \\
\text { workers }\end{array}$ & $\begin{array}{l}\text { U.S. MNC: Medium } \\
\text { Finish MNC: Medium } \\
\text { Though tendency towards stronger separation visible } \\
\text { German MNC: Medium }\end{array}$ & $\begin{array}{l}\text { U.S. MNC: High } \\
\text { Finish MNC: Medium } \\
\text { German MNC: High } \\
\text { Bridged by paternalist style of Managing Director }\end{array}$ \\
\hline & $\begin{array}{l}\text { Strength of trade } \\
\text { unions/Works } \\
\text { councils }\end{array}$ & $\begin{array}{l}\text { High in all subsidiaries } \\
\text { In the Finnish MNC there are attempts being made to weaken the } \\
\text { position of works councils }\end{array}$ & $\begin{array}{l}\text { U.S. MNC, Finish MNC: Low } \\
\text { No particular role for works councils } \\
\text { German MNC: Medium to High } \\
\text { Considerable strength through membership in European Works Council } \\
\text { of the multinational group }\end{array}$ \\
\hline
\end{tabular}

Table 4: The work systems in the German and British subsidiaries compared (to be continued on next page) 


\begin{tabular}{|l|l|l|l|}
\hline & $\begin{array}{l}\text { Employer } \\
\text { commitment to } \\
\text { employment } \\
\text { Employment } \\
\text { practices and } \\
\text { policies }\end{array}$ & $\begin{array}{l}\text { U.S. MNC: High } \\
\text { Finish MNC: High } \\
\text { German MNC: Very High }\end{array}$ & $\begin{array}{l}\text { U.S. MNC: Very Low } \\
\text { Finish MNC: Medium } \\
\text { German MNC: Medium to Low }\end{array}$ \\
& $\begin{array}{l}\text { Employer } \\
\text { commitment to } \\
\text { skill development }\end{array}$ & $\begin{array}{l}\text { U.S. MNC: Medium } \\
\text { Finish MNC: High, but recently declining } \\
\text { German MNC: High }\end{array}$ & $\begin{array}{l}\text { U.S. MNC, German MNC: Very Low } \\
\text { Finish MNC: Medium to High } \\
\text { Though recently discouraged through higher staff turnovers }\end{array}$ \\
\hline
\end{tabular}

Table 4: The work systems in the German and British subsidiaries compared 


\begin{tabular}{|c|c|c|}
\hline & $\begin{array}{l}\text { Element of work system } \\
\text { which is object of 'cherrypicking' } \\
\text { strategy in host country }\end{array}$ & $\begin{array}{l}\text { Limits to the 'cherrypicking' strategy } \\
\text { imposed by the national business } \\
\text { system of the host country }\end{array}$ \\
\hline U.S. MNC & $\begin{array}{l}\text { Britain: } \\
\text { Benefiting from fragmentation and } \\
\text { weak employment relations in closing } \\
\text { manufacturing operations } \\
\text { Germany: } \\
\text { Benefiting from highly integrated work } \\
\text { system, high skill level, high } \\
\text { productivity for global sourcing of } \\
\text { engineering, R\&D and manufacturing } \\
\text { of customized special products }\end{array}$ & $\begin{array}{l}\text { Britain: } \\
\text { Initial loss of customers who preferred } \\
\text { buying from British manufacturing } \\
\text { plant } \\
\text { Germany: } \\
\text { Relatively isolated position of German } \\
\text { subsidiary within the multinational } \\
\text { group as supplier of high-tech } \\
\text { components and products; low level } \\
\text { of integration within group-wide work } \\
\text { systems of German subsidiary }\end{array}$ \\
\hline $\begin{array}{l}\text { Finnish } \\
\text { MNC }\end{array}$ & $\begin{array}{l}\text { Britain: } \\
\text { Benefiting from artisanal work system } \\
\text { to manufacture customized products } \\
\text { Germany: } \\
\text { Benefiting from high skill level for } \\
\text { R\&D and developing new products }\end{array}$ & $\begin{array}{l}\text { Britain: } \\
\text { Problems of recruiting and losing } \\
\text { skilled workers to competitors in the } \\
\text { service sector } \\
\text { Germany: } \\
\text { Strong resistance to fragmentation of } \\
\text { the work system and to losing control } \\
\text { of the work organization; result: } \\
\text { replacement of local managers by } \\
\text { managers from other parts of the } \\
\text { group and from HQ }\end{array}$ \\
\hline
\end{tabular}

Table 5: Characteristics of a 'cherrypicking' strategy in the U.S. and Finnish MNC 